\title{
Effect of omitting one or two milkings weekly on lactational performance in dairy ewes
}

\author{
Gonzalo Hervás ${ }^{1}$ t, Jorge L Ramella ${ }^{2 *}$, Secundino López ${ }^{2,3}$, Jesús S González ${ }^{2,3}$ \\ and Ángel R Mantecón ${ }^{1,3}$ \\ ${ }^{1}$ Estación Agrícola Experimental, Consejo Superior de Investigaciones Científicas (CSIC), Apdo 788, 24080 León, Spain \\ ${ }^{2}$ Departamento de Producción Animal I, Universidad de León (ULE), 24071 León, Spain \\ ${ }^{3}$ Unidad Asociada Nutrición-Praticultura CSIC-ULE, León, Spain
}

Received 17 June 2005 and accepted for publication 14 September 2005

\begin{abstract}
We investigated the effects of omitting one or two milkings weekly on milk yield and milk composition in dairy sheep. Ninety Spanish Assaf ewes were allocated to three experimental treatments: $\mathrm{T}_{0}$ (no milking omission; 14 milkings/week), $\mathrm{T}_{1}$ (omission of one evening milking per week; 13 milkings/week) and $\mathrm{T}_{2}$ (omission of two evening milkings per week; 12 milkings/ week). The experiment was extended for 11 weeks, from week 7 after lambing to week 17 of lactation. Once a week, daily milk production was recorded just before and after the omission. Milk quality and composition was analysed in lactation weeks 9, 13 and 16. Omission of one or two evening milkings each week resulted in an increase in milk production recorded the day immediately after the omission $\left(27 \%\right.$ for $\mathrm{T}_{1}$ and $16 \%$ for $\left.\mathrm{T}_{2}\right)$, which can be attributed to accumulation of milk in the udder cisterns. This increase did not compensate completely for the loss of yield in the omitted milking. The lack of significant differences among the three milking strategies in milk production (on average 1903, 2062 and $1833 \mathrm{ml} / \mathrm{d}$ for $\mathrm{T}_{0}, \mathrm{~T}_{1}$ and $\mathrm{T}_{2}$, respectively) recorded before omission throughout the trial, would indicate the absence of residual effects of the omission on production in subsequent weeks. Treatment $T_{2}$ resulted in a loss of milk production of approximately $39 \%$ during those days when milkings were omitted, representing a decrease of approximately $10 \%$ of the estimated weekly milk production. In relation to milk composition, milking omission led to significant increases in the fat and protein concentrations of the milk collected after the omission, whereas differences were not significant for the milk obtained before the omission. Despite the slight increase observed in treatment $\mathrm{T}_{2}$ after the milking omission, the somatic cell count was always far below that considered as indicative of possible pathologies. In conclusion, at least one evening milking could be omitted each week in high-producing dairy sheep without adversely affecting milk yield and milk composition.
\end{abstract}

Keywords: Assaf, dairy sheep, milking frequency, milk yield, milk composition.

Historically, sheep milk production has been considered to be restricted to less favoured areas owing to its importance in some parts of Africa or Asia. Recently, however, sheep milk is in increasing demand in Europe, especially in the Mediterranean countries, becoming a really interesting alternative for the manufacture of high-quality and valuable dairy products (Mantecón, 1999). One-third of the world's sheep milk production is obtained from countries of the Mediterranean basin (FAO, 2004), where most

+For correspondence; e-mail: hervas@eae.csic.es *Present address: UDESC, Lages-Santa Catarina, Brazil. sheep are farmed in small flocks by the owner and his family. In most of these farms, ewes are milked generally twice a day (once in the morning and once in the evening) with a time interval as near as possible to $12 \mathrm{~h}$. This practice constitutes one of the most important constraints to this sector's expansion, as it does not allow for any break in the farmer's activity. For this reason, any possible reduction in the number of milkings would undoubtedly imply a significant improvement in farmers' quality of life. Some studies examining the effects of reducing the frequency of milking in sheep and cows, have shown that milk production can be negatively affected by less frequent milkings, although the magnitude of this effect would 
depend mostly on the milking schedule (number of milkings per week, milking interval), the breed of dairy sheep and the lactation stage (Labussière, 1988; Davis et al. 1999), so further investigation seems timely.

Although some authors have reported an important reduction in milk yield when animals are milked only once (morning milking) during most of their lactation (Papachristoforou et al. 1982; Holmes et al. 1992; O'Brien et al. 2002; Rémond et al. 2004; Castillo et al. 2005), some studies in New Zealand show that omission of one daily milking towards the end of the lactation is a common practice on dairy farms, given the minor loss in milk yield (Knight \& Gosling, 1995) observed when the level of production declines in late lactation (Davis et al. 1999).

Omission of some occasional milkings during the week, preferably towards the weekend, would be a more desirable alternative for family farms, but information on this topic is rather scarce and controversial. Some authors (Casu \& Labussière, 1972; Labussière et al. 1974) have reported a significant decrease in milk production in Sarda and Préalpes de Sud ewes when one or two milkings were omitted weekly, whereas other researchers (Huidobro, 1988; Knight \& Gosling, 1995) did not observe any statistically significant differences in Manchega and Poll Dorset ewes, suggesting that the dairy sheep breed is likely to be an important factor determining the effects of the omission of one or more milkings weekly on performance. Omission of some milkings weekly can also affect milk composition (Casu \& Labussière, 1972; Labussière et al. 1974; Knight \& Gosling, 1995; Rémond et al. 2004) and udder health (Holmes et al. 1992; O'Brien et al. 2002), although both points have received little attention.

Despite the importance of sheep breed, no studies have been carried out with Assaf ewes. This high-yielding dairy sheep breed was developed in Israel in the 1950s and 1960s (Pollott \& Gootwine, 2004) and was introduced into Spain between 1977 and 1980, progressively replacing, through successive crosses leading to a process of absorption, most indigenous local breeds (e.g. Churra or Castellana; Ugarte et al. 2001). Nowadays, Assaf sheep are bred in most dairy farms, particularly those located in north-western Spain (Martínez et al. 1999; Mantecón \& Lavín, 2001), where sheep milk is becoming a valuable product for local cheese manufacture.

This study was conducted to investigate the effects of omitting one or two milkings weekly on milk yield and milk composition in Spanish Assaf dairy ewes.

\section{Materials and Methods}

The experiment was carried out in accordance with the European Council Directive 86/609/ECC for the protection of animals used for experimental and other scientific purposes.

\section{Animals and their diet}

Ninety Spanish Assaf ewes (2-5 years old and with live weight of $70 \cdot 3 \pm 1 \cdot 60 \mathrm{~kg}$ ) were used. All the animals were managed similarly throughout the trial and maintained under the same feeding system during the course of the experiment, based on grazing an irrigated sward of Lolium multiflorum for $12 \mathrm{~h}$ a day, with each animal receiving, in the stable, a supplement of $600 \mathrm{~g}$ daily of a concentrate feed ( $45 \%$ barley, $25 \%$ corn, $27 \%$ soyabean meal $44 \%$ and $3 \%$ vitamin-mineral supplement) and grass hay and beet pulp silage offered ad libitum.

\section{Experimental treatments}

Milk production was recorded in all sheep at week 6 after lambing, and animals were allocated to three groups according to their level of milk yield: high $(>2500 \mathrm{ml} / \mathrm{d})$, medium $(2000-2500 \mathrm{ml} / \mathrm{d})$ and moderate $(<2000 \mathrm{ml} / \mathrm{d})$. Then, experimental treatments (defined by the number of milkings per week) were assigned at random within each group following a randomized complete block design. By blocking the sheep into homogeneous groups, some of the variability associated with the level of production was removed, allowing for detecting smaller differences between treatments. The three experimental treatments were:

- $\mathrm{T}_{0}$ : animals were milked twice a day, seven days a week (14 milkings/week)

- $\mathrm{T}_{1}$ : the evening milking was omitted on only one day of the week (13 milkings/week),

- $\mathrm{T}_{2}$ : the evening milking was omitted in two consecutive days (12 milkings/week)

Ewes were milked every day at 07.30 (morning milking) and 05.30 (evening milking) in a double-12 stall parallel milking parlour (Westfalia Landtechnik, Barcelona, Spain) and the milking machine (vacuum pump, cup clusters, inflations and pulsators; Westfalia Landtechnik, Barcelona, Spain) was operated at a vacuum of $42 \mathrm{kPa}$ and pulsation of $45 \mathrm{pulses} / \mathrm{min}$. The milking routine for the regular daily milking included teat cleaning, machine stripping (i.e. massaging the udder and pulling down on the cups) and teat dipping (Alfadine ${ }^{\circledR}$, DeLaval, Barcelona, Spain). The experiment was extended for 11 weeks, from week 7 after lambing to week 17 of lactation.

\section{Measurements}

Live weight. Animals were weighed at weeks 6, 7, 13 and 17 after lambing, using a mobile scale (Magriñá 102 III, Barcelona, Spain).

Milk production. Daily milk production was recorded in each animal during the morning and evening milkings, using individual percentage meters (Tru Test Distributors Ltd, Auckland, New Zealand). For the control group $\left(T_{0}\right)$, 


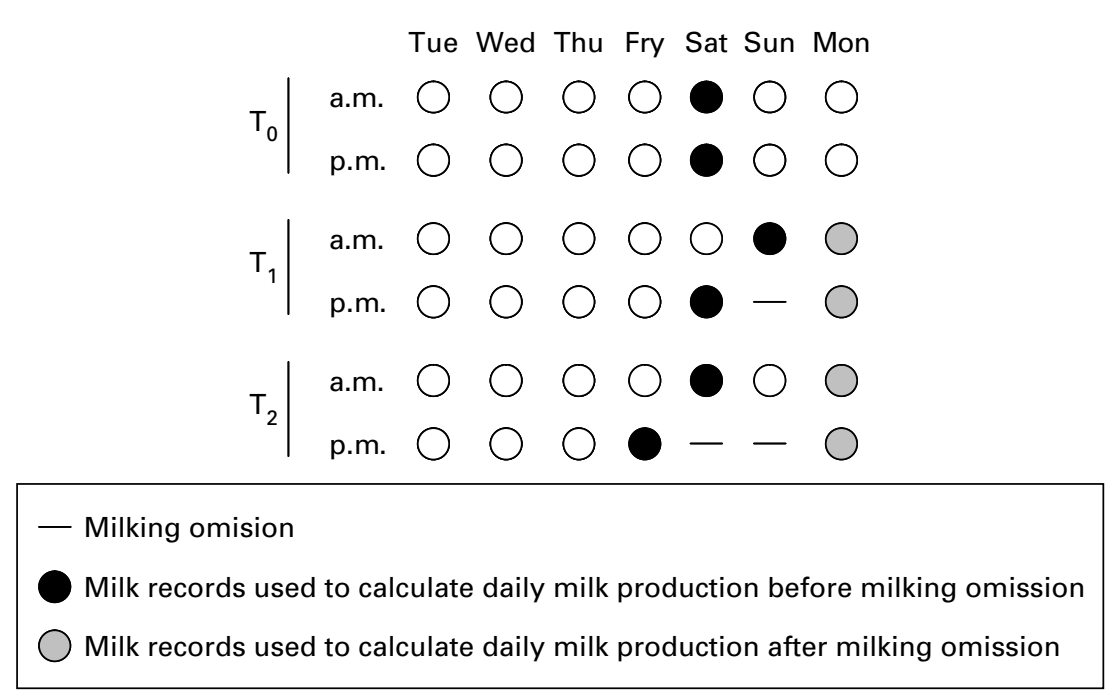

Fig. 1. Milking weekly schedule for each experimental treatment $\left(T_{0}, T_{1}\right.$ and $\left.T_{2}\right)$ and milk records used to calculate daily milk production before and after milking omission for each group of animals.

milk production was recorded one day per week (Fig. 1); however, for treatments $\mathrm{T}_{1}$ and $\mathrm{T}_{2}$, yield records were taken in the two milkings previous to the evening when the ewes were not milked, and also in both milkings of the day after the omission (see Fig. 1), such that daily milk production was measured just before and after the omission.

Milk quality and composition. In lactation weeks 9, 13 and 16 a representative milk sample $(40 \mathrm{ml})$ was collected from each animal at each milking when yield records were undertaken (in animals of treatments $T_{1}$ and $T_{2}$, both before and after the omission). Fat, protein and total solids contents were analysed in these samples, and somatic cell count (SCC) was determined. Upon collection, samples were preserved with $0 \cdot 1 \mathrm{~g}$ potassium dichromate (Panreac Química S. A., Barcelona, Spain) and stored at $4{ }^{\circ} \mathrm{C}$ until subsequent laboratory analyses.

\section{Chemical analysis}

Fat, protein and total solids contents were determined by automatic infrared spectrophotometry using a MilkoScan 255 A/S N (Foss Electric, Hillerød, Denmark). Milk SCC was carried out by a fluoro-opto-electronic technique using a Fossomatic $90 \mathrm{~A} / \mathrm{S} N$ (Foss Electric), with a contrast against a direct microscopic method (IDF, 1984) using three different dyes: methylene blue (IDF, 1991), May-Grünwald-Giemsa and methyl Pyronin green (Paape et al. 1963; Dulin et al. 1982).

\section{Calculations and statistical analysis}

For treatment $\mathrm{T}_{0}$ daily milk production (DY) was calculated as the sum of yields recorded in morning $(\mathrm{Mm})$ and evening (Em) milkings carried out within the same day (i.e. $D Y=M m+E m$ ). For treatments $T_{1}$ and $T_{2}$, daily milk production before omission was calculated as the sum of the production obtained from the morning milking (Mbo) of the same day when the first milking was omitted, and that obtained from the evening milking of the previous day (Ebo). Daily production after omission was calculated as the sum of the yields recorded in the two milkings (Mao and Eao) carried out the day after the last omission (see Fig. 1).

Average milk production rates $(\mathrm{ml} / \mathrm{h})$ were calculated from the yields recorded the day before and after the milking omitted and the time interval between milkings. Thus, the average production rate before omission was calculated as (Mbo+Ebo)/24, whereas after the omission, the average rate of milk production was estimated as (Mao+Eao)/34. An index of lactation persistency was calculated as the regression slope between the daily milk production before the omission and lactation week.

From the milk chemical composition data (fat, protein and total solids concentration), the daily production of each component before and after the omitted milking was calculated. SCC values were logarithmically transformed $\left(\log _{10} / \mathrm{ml}\right)$.

Daily milk production, average milk production rate, chemical composition and SCC measured before and after omission were considered as different variables and analysed with a mixed linear model by ANOVA according to a split-plot in time design, considering sheep as main experimental units, level of production as a blocking factor, number of milkings omitted weekly $(0,1$ or 2$)$ as the levels of the whole-unit treatment, and records in successive lactation weeks as repeated observations on the same experimental unit. The resulting model was:

$\mathrm{Y}_{i j k l}=\mu+\mathrm{T}_{i}+\mathrm{L}_{j}+\mathrm{A}_{k(i j)}+\mathrm{W}_{l}+\mathrm{TW}_{i l}+\varepsilon_{i j k l}$ 
Table 1. Average daily milk production $(\mathrm{ml} / \mathrm{d})$ and milk production rate $(\mathrm{ml} / \mathrm{h})$ before and after milking omission, and lactation persistency index ( $\mathrm{ml} / \mathrm{d}$ per week) in sheep milked twice every day $\left(\mathrm{T}_{0}\right)$, or when either one (treatment $\mathrm{T}_{1}$ ) or two (treatment $\mathrm{T}_{2}$ ) milkings were omitted each weekt

\begin{tabular}{|c|c|c|c|c|c|c|c|}
\hline & \multicolumn{3}{|c|}{ Treatment } & \multirow[b]{2}{*}{$\mathrm{RSD}_{\mathrm{t}} \S$} & \multicolumn{3}{|c|}{ Level of Significance, $P \neq$} \\
\hline & $\mathrm{T}_{0}$ & $\mathrm{~T}_{1}$ & $\mathrm{~T}_{2}$ & & $\mathrm{~T}$ & W & $\mathrm{T} \times \mathrm{W}$ \\
\hline \multicolumn{8}{|c|}{ Daily milk production, $\mathrm{ml} / \mathrm{d}$} \\
\hline Before & 1903 & 2062 & 1833 & $296 \cdot 8$ & NS & $* * *$ & NS \\
\hline After & $1903^{\mathrm{c}}$ & $2600^{\mathrm{a}}$ & $2107^{\mathrm{b}}$ & $349 \cdot 7$ & $* * *$ & $* * *$ & * \\
\hline $\operatorname{RSD}_{0} \uparrow$ & - & $328 \cdot 0$ & $377 \cdot 3$ & & & & \\
\hline$P \neq$ & - & $* * *$ & $* * *$ & & & & \\
\hline \multicolumn{8}{|c|}{ Average milk production rate, $\mathrm{ml} / \mathrm{h}$} \\
\hline Before & $79 \cdot 3$ & $85 \cdot 9$ & $76 \cdot 4$ & $12 \cdot 37$ & NS & $* * *$ & NS \\
\hline After & $79 \cdot 3^{a}$ & $76 \cdot 5^{a}$ & $62 \cdot 0^{\mathrm{b}}$ & $11 \cdot 23$ & $* * *$ & $* * *$ & NS \\
\hline $\operatorname{RSD}_{\mathrm{O}} \boldsymbol{\top}^{2}$ & - & $11 \cdot 29$ & $13 \cdot 24$ & & & & \\
\hline$P \neq$ & - & $* * *$ & $* * *$ & & & & \\
\hline \multicolumn{8}{|c|}{ Lactation persistency index, $\mathrm{ml} / \mathrm{d}$ per week } \\
\hline & $-95 \cdot 2$ & $-96 \cdot 0$ & $-104 \cdot 2$ & $67 \cdot 59$ & NS & - & - \\
\hline 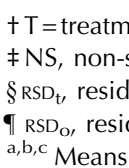 & \multicolumn{7}{|c|}{$\begin{array}{l}+\mathrm{T}=\text { treatment effect; } \mathrm{W}=\text { week of lactation effect; } \mathrm{T} \times \mathrm{W}=\text { interaction } \\
\neq \mathrm{NS} \text {, non-significant }(P>0 \cdot 05) ; * P<0 \cdot 05 ; * * * P<0 \cdot 001 \\
\mathrm{RSD}_{\mathrm{B}} \text {, residual standard deviation for the comparison among treatments }\end{array}$} \\
\hline
\end{tabular}

where $Y_{i j k l}$ is the individual value of each dependent variable; $\mu$, the overall mean; $\mathrm{T}_{i}$, the treatment effect $\left(i=\mathrm{T}_{0}, \mathrm{~T}_{1}\right.$ and $\left.\mathrm{T}_{2}\right) ; \mathrm{L}_{j}$, the block effect attributed to level of milk production ( $j=$ high, medium, moderate); $A_{k(i j) \text {, }}$ the random effect of the $k$ th animal nested within the experimental treatment $i$ and the level of production $j$; $W_{l}$, the effect of the lactation week; $\mathrm{TW}_{i l}$, the effect of the interaction between experimental treatment and the week; and $\varepsilon_{i j k l}$, the residual error (subplot error).

Furthermore, within treatments $T_{1}$ and $T_{2}$, values recorded before and after milking omission were considered as repeated measures on the same experimental unit and compared by using the following model:

$\mathrm{Y}_{i j k l}=\mu+\mathrm{L}_{i}+\mathrm{A}_{j(i)}+\mathrm{O}_{k}+\mathrm{AO}_{j k(i)}+\mathrm{W}_{l}+\mathrm{OW}_{k l}+\varepsilon_{i j k l}$

where $\mathrm{Y}_{i j k l}$ is the value of each observation for the dependent variable; $\mu$, the overall mean; $L_{i}$, the block effect attributed to level of milk production ( $i=$ high, medium, moderate); $\mathrm{A}_{j(i)}$, the random effect of the $j$ th animal nested within the level of production $i ; \mathrm{O}_{k}$, the effect of milking omission on each experimental unit ( $k=$ before or after omission); $\mathrm{AO}_{j k(i)}$, the interaction between $\mathrm{A}_{j(i)}$ and $\mathrm{O}_{k}$, used as the error term to test the significance of the effect of $\mathrm{O}_{k} ; \mathrm{W}_{l}$, the effect of lactation week; $\mathrm{OW}_{k l}$, the effect of the interaction between milking omission and lactation week; and $\varepsilon_{i j k l}$, the residual error.

Statistical analyses were performed using the GLM procedure of the Statistical Analysis System package (SAS, 1999), and comparisons between multiple means was carried out using the Duncan test $(P<0 \cdot 05)$.

\section{Results}

No significant $(P>0.05)$ live weight variations attributed to the experimental treatments were found (results not shown). As expected, omission of some milkings weekly increased significantly $(P<0.001)$ milk production recorded the day immediately after the omission $(27 \%$ for $\mathrm{T}_{1}$ and $16 \%$ for $\mathrm{T}_{2}$; see Table 1$)$. However, this increase was associated with a significant decline in average milk production rate when two milkings were omitted $(79 \cdot 3$ v. $62.0 \mathrm{ml} / \mathrm{h}$, for $\mathrm{T}_{0}$ and $\mathrm{T}_{2}$, respectively; $\left.P<0.001\right)$. The significant increase in total milk yielded the day after omission along with a lower average rate of production were confirmed when values recorded before and after the omission were compared within treatments $T_{1}$ and $T_{2}$, $(P<0 \cdot 001)$. There was a steady decay in milk production (daily yield and average rate of production) throughout the lactation (Fig. 2) resulting in significant effects $(P<0 \cdot 001)$ of lactation week on these performance traits. There were no significant $(P>0 \cdot 05)$ differences between treatments in lactation persistency index (Table 1), with an overall mean decay in daily milk production of $98.4 \mathrm{ml}$ each week.

In relation to milk composition (Table 2), significant differences were detected between treatments $T_{2}$ and control $\left(\mathrm{T}_{0}\right)$ or treatment $\mathrm{T}_{1}$ in the fat content $(P<0 \cdot 01)$ of the milk collected in the milkings after omission, whereas differences were not significant for the milk obtained before the omission, suggesting a lack of residual effects of milking omission on the composition of the milk obtained a few days after omission. For treatment $\mathrm{T}_{2}$, fat content was $16 \%$ higher in the milk collected after omission in 
Table 2. Chemical composition (\%) and somatic cell count (SCC, $\log _{10} / \mathrm{ml}$ ) of the milk collected before and after milking omission in sheep milked twice every day $\left(T_{0}\right)$, or when either one (treatment $T_{1}$ ) or two (treatment $T_{2}$ ) milkings were omitted each week $t$

Treatment

$\overline{\mathrm{T}_{0}} \quad \mathrm{~T}_{2}$

Milk composition, \%

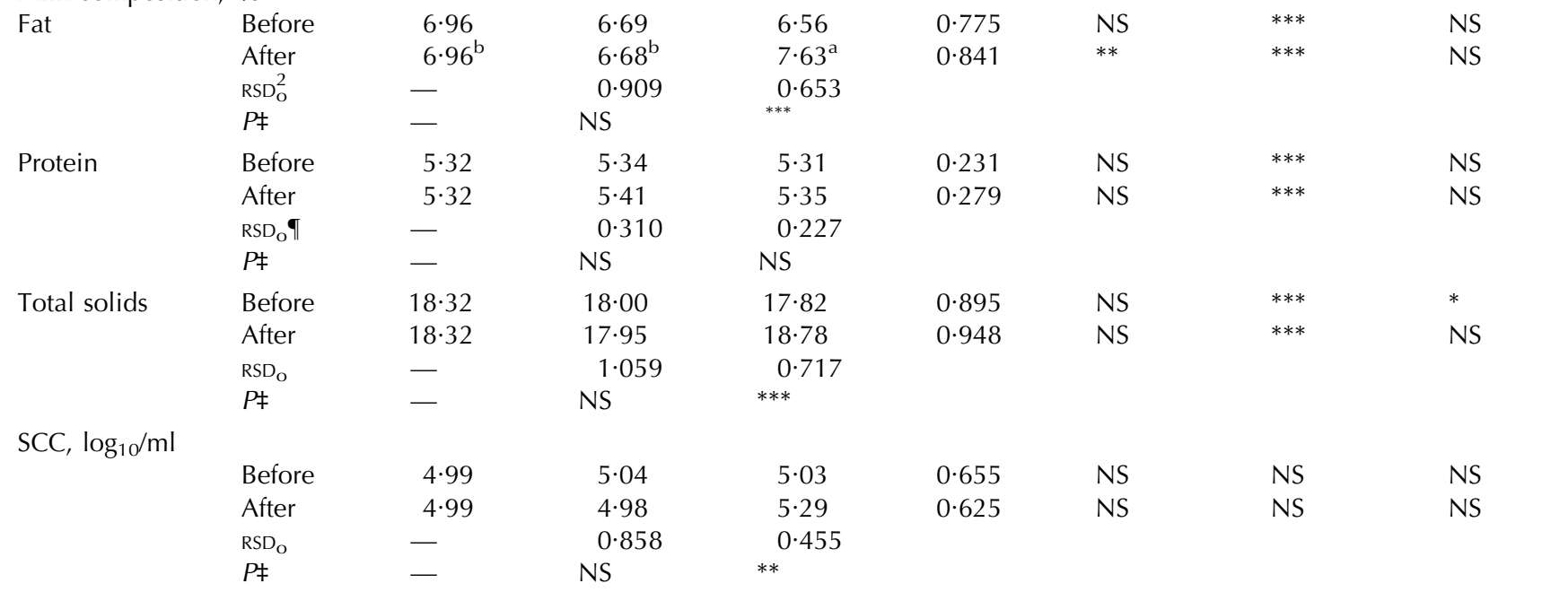

$\mathrm{T} \mathrm{T}=$ treatment effect; $\mathrm{W}=$ week of lactation effect; $\mathrm{T} \times \mathrm{W}=$ interaction ‡NS, non-significant $(P>0 \cdot 05)$; $P<0 \cdot 05$; ** $P<0.01$; *** $P<0.001$

$\S \mathrm{RSD}_{\mathrm{t}}=$ residual standard deviation for the comparison among treatments within each row

I $R \mathrm{RD}_{\mathrm{o}}=$ residual standard deviation for the comparison between values recorded before or after the milking omission within each treatment

$\mathrm{a}, \mathrm{b}$ Means in a row with different letters differ significantly $(P<0 \cdot 05)$

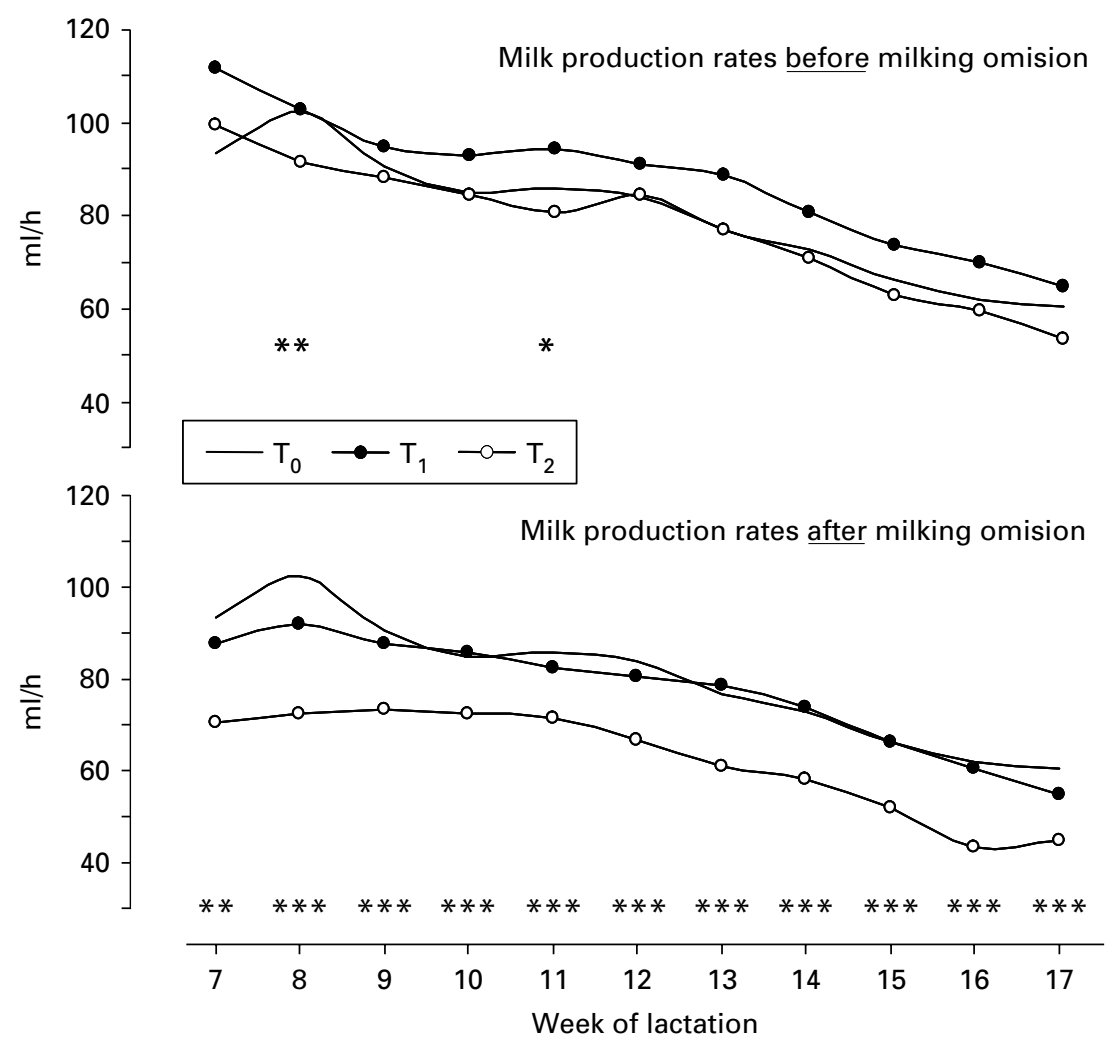

Fig. 2. Average milk production rates before $(\mathrm{RSD}=12 \cdot 37)$ and after $(\mathrm{RSD}=11 \cdot 23)$ milking omission for each experimental treatment $\left(\mathrm{T}_{0}, \mathrm{~T}_{1}\right.$ and $\left.\mathrm{T}_{2}\right)$, between weeks 7 and 17 of lactation $\left(* P<0 \cdot 05 ; * * P<0 \cdot 001 ;{ }^{* * *} P<0 \cdot 001\right)$. 
Table 3. Fat, protein and total solids daily production $(\mathrm{g} / \mathrm{d})$ from the milk collected before and after milking omission in sheep milked twice every day $\left(T_{0}\right)$, or when either one (treatment $T_{1}$ ) or two (treatment $T_{2}$ ) milkings were omitted each weekt

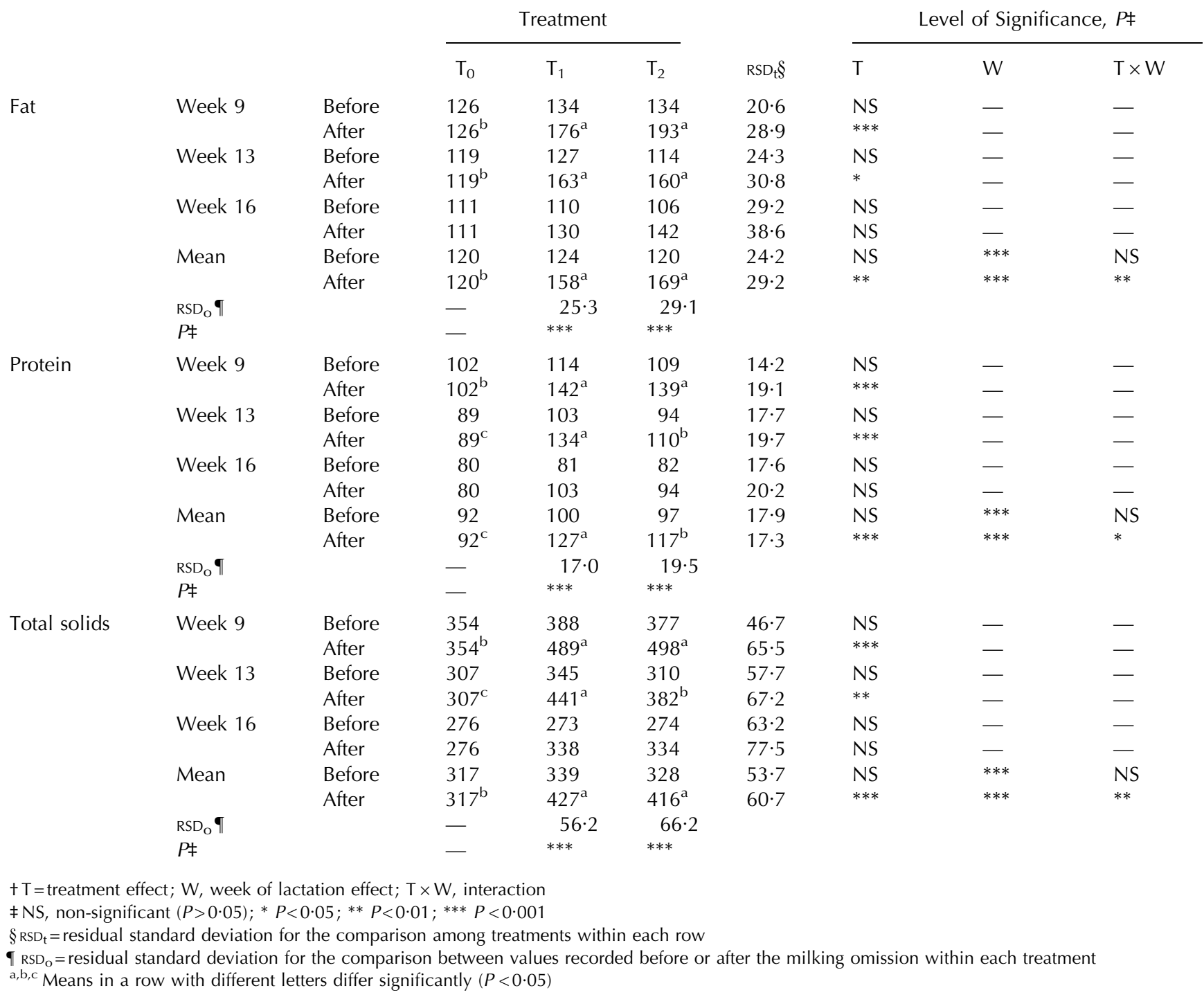

comparison with that obtained before the omission $(P<0 \cdot 001)$, whereas no differences in composition between milk collected before and after omission were found within treatment $T_{1}$. As for the other milk components (protein and total solids), only in $\mathrm{T}_{2}$ was there a $5.4 \%$ increase in total solids after the omission (17.82 $\mathrm{v}$. $18.78 \% ; P<0.001)$. As expected, lactation stage affected significantly $(P<0.001)$ the milk composition, with all components increasing slightly from week 9 to week 16 of lactation. This trend was similar in the three experimental treatments, and thus the interaction 'treatment $\times$ lactation week' was not significant $(P>0.05)$ in most cases. Treatment and lactation week effects on SCC (Table 2) were not statistically significanct $(P>0.05)$, although a slight increase in SCC $(5 \% ; P<0.01)$ was observed in the milk produced after the last omission when the evening milking was omitted for two consecutive days $\left(T_{2}\right)$.

When daily output of each milk component (fat, protein, total solids) was analysed, it revealed a significant $(P<0 \cdot 05)$ interaction 'treatment $\times$ lactation week'. Therefore, these values are presented for each week when milk composition was determined (Table 3). Omitting one or two evening milkings each week significantly increased $(P<0 \cdot 01)$ fat production $(32 \%$ and $41 \%$ for treatments $\mathrm{T}_{1}$ and $\mathrm{T}_{2}$, respectively), as well as protein production (38\% and $27 \%$ for $\mathrm{T}_{1}$ and $\mathrm{T}_{2}$ ) and total solids $(35 \%$ and $31 \%$ for $\mathrm{T}_{1}$ and $\mathrm{T}_{2}$ ) in the milk obtained the day after the last milking omission. In both treatments $\left(T_{1}\right.$ and $\left.T_{2}\right)$, fat, protein and total solids production were greater $(P<0 \cdot 001)$ after than before milking omission. Differences between 
Table 4. Increase in milk production observed after omission relative to the milk yield recorded the day before omission (ml increment per litre milk yield recorded before omission) and proportion of milk obtained in the evening milking relative to the total daily production $(\mathrm{ml}$ milk obtained in the evening milking per litre of daily milk production) the days before and after the omissiont

\begin{tabular}{|c|c|c|c|}
\hline \multirow[b]{2}{*}{ Treatment } & \multirow{2}{*}{$\begin{array}{l}\text { Increment } \\
\text { After-Before }\end{array}$} & \multicolumn{2}{|c|}{$\begin{array}{l}\text { Milk production obtained in the evening } \\
\text { milking relative to the daily yield }\end{array}$} \\
\hline & & Before omission & After omission \\
\hline Level of production & Before & & \\
\hline Treatment $\mathrm{T}_{0}$ & - & 417 (SE 4·4) & - \\
\hline High & - & 420 & - \\
\hline Medium & - & 416 & - \\
\hline Moderate & - & 415 & - \\
\hline Treatment $\mathrm{T}_{1}$ & $274($ SE 15·3) & $410(\mathrm{SE} 4 \cdot 4)$ & $284(\mathrm{SE} 4 \cdot 0)$ \\
\hline High & 278 & 405 & 283 \\
\hline Medium & 252 & 416 & 288 \\
\hline Moderate & 296 & 413 & 281 \\
\hline Treatment $\mathrm{T}_{2}$ & 162 (SE 15·6) & $419(\mathrm{SE} 5 \cdot 4)$ & $336($ SE $5 \cdot 1)$ \\
\hline High & 200 & 417 & 328 \\
\hline Medium & 164 & 435 & 339 \\
\hline Moderate & 125 & 409 & 341 \\
\hline Overall mean & $142($ SE $8 \cdot 3)$ & $415($ SE $2 \cdot 7)$ & $310(\mathrm{SE} 3 \cdot 5)$ \\
\hline
\end{tabular}

$+\mathrm{T}_{0}=$ no milking omission; $\mathrm{T}_{1}=$ omission of one evening milking per week; $\mathrm{T}_{2}=$ omission of two evening milkings per week

experimental treatments in fat, protein and total solids production in the milk obtained after omission were larger at week 9 of lactation and tended to be reduced towards late lactation, such that differences were not significant $(P>0.05)$ at week 16 .

\section{Discussion}

Using high-producing Spanish Assaf ewes, the omission of one or two evening milkings each week, resulted in an important increase in milk production recorded the day immediately after the omission (on average $27 \%$ for $\mathrm{T}_{1}$ and $16 \%$ for $\mathrm{T}_{2}$ ), compared with the production recorded the day before the omission (Table 4). Of the daily milk recorded before omission, $41.5 \%$ is produced from the evening milking (Table 4) and is the loss of production that could be expected from the omission of one evening milking. However, the increase in daily milk production after an evening omission can be attributed to the accumulation of milk in udder cisterns, making up for the milk not withdrawn at the omitted milking. The difference between before-omission and after-omission records in the milk obtained in the evening milking, as a proportion of the total daily production (Table 4), also corroborates that milk not withdrawn in the milking omitted is retained in the mammary gland, and recovered partly in the next milking. Thus, whereas the milk obtained in the morning milking before omission averages $58.5 \%$ of the daily yield, after the omission this percentage rises to $69.0 \%$ on average, including milk not obtained in the omitted milking. Ayadi et al. (2003) observed that the compensatory increase in milk production following the omission of one milking weekly in cows was extended for up to $2 \mathrm{~d}$. The cisternal capacity to accumulate milk when milking is omitted is one of the main factors responsible for the animal response to this kind of management, and shows significant differences among breeds (Casu \& Labussière, 1972; Labussière, 1988; Knight \& Dewhurst, 1994; Davis et al. 1998, 1999; Castillo et al. 2005). On the other hand, the omission of one or more milkings could also cause an increase in the intramamary pressure (Peaker, 1980) or a reduction of the alveolar drainage (Davis et al. 1998), which could negatively affect milk secretion and production. This could explain why average milk production rate for the milking carried out after the omission was significantly lower $(P<0.001)$ for treatment $\mathrm{T}_{2}$ animals (see Fig. 2). Nevertheless, the lack of effects of milking omission on milk production (Table 1) or on average milk production rate (Fig. 2) recorded before omission throughout the trial, or on lactation persistency index (Table 1) would indicate the absence of residual effects of the omission on production in subsequent weeks. Yield was recorded only one day after omission, and then one week later prior to the following milking omission. As the level of milk yield before omission was similar in two consecutive weeks, it was assumed that the main impact of the omission would be just on the day after omission and of less significance on the following days. If milk production were depressed during those intermediate days, the effect of milking omission would have been more severe, resulting in higher decreases in milk yield than those seen in the present work.

Consequently, the omission of two evening milkings each week (treatment $\mathrm{T}_{2}$ ) would result in a loss of milk production of approximately 39\% just during those days 
when milkings are omitted, representing a decrease of approximately $10 \%$ of the estimated weekly milk production. With the omission of only one evening milking each week, the loss of production is approximately $14 \%$ considering the days before and after the omission, with a small repercussion on the estimated weekly production. This is in agreement with results reported by other authors when one or more milkings are omitted weekly in dairy sheep (Casu \& Labussière, 1972; Labussière et al. 1974) or cattle (Ayadi et al. 2003), although recently McKusick et al. (2002) reported no effects in dairy ewes. The milk production reduction observed in this trial is not as important as with animals milked only once daily (Knight \& Dewhurst, 1994; Knight \& Gosling, 1995; O'Brien et al. 2002; Salama et al. 2003; Rémond et al. 2004) where the average decrease in milk production accounts for up to more than $30 \%$ compared with twice-daily milking. It is noteworthy that in treatment $\mathrm{T}_{2}$ the evening milking was omitted twice weekly in two consecutive days, with a 5-d interval between two omission periods. Given the small response observed when only one evening milking was omitted each week, it might be feasible that two non-consecutive omissions distributed more regularly during the week (i.e. omissions on Sunday and Thursday), would result in less pronounced effects on milk production than those observed with treatment $T_{2}$, assuming that the accumulation of milk in the mammary cisterns would occur to a lesser extent than when milking omission is in two consecutive days.

Nevertheless, the decrease in milk production attributed to the omission of some milkings weekly may be variable, mainly depending on two animal factors (Labussière, 1988): the sheep breed, determinant of characteristics such as the potential of production, mammary morphology or cisternal capacity, and the level of production of each animal. Labussière (1988) concluded that variations between breeds could be one of the main factors responsible for the apparently contradictory results reported in the literature examining the effects of milking omission in dairy sheep and cattle. In this sense, the omission of one or more milkings each week has resulted in milk production decreases ranging from $13 \%$ in Sarda ewes (Casu \& Labussière, 1972), to $69 \%$ in Tsigaya ewes (Mikus et al. 1983). In contrast with these results, Huidobro (1988) did not observe any significant effect on milk production in Manchega ewes attributed to the omission of the Sunday evening milking. In relation to the level of production, in the present study this factor was considered only as a blocking factor, as preliminary results revealed that in most cases the interaction between treatment (number of milkings omitted each week) and level of production was not statistically significant (results not shown). Furthermore, results reported in the literature seem to indicate that possible effects of milking omission become less noticeable as milk yield declines in late lactation in ewes (Geenty \& Davison, 1982; Knight \& Gosling, 1995; Castillo et al. 2005). Based on this assumption, many
New Zealand dairy sheep farmers have adopted the practice of milking only once daily during late lactation without drastically affecting commercial milk production (Geenty \& Davison, 1982; Knight \& Gosling, 1995; Davis et al. 1999). In our study, omission of one or two milkings each week was applied between lactation weeks 7 and 17, and no significant differences were observed $(P>0.05)$ between treatments in lactation persistency index, so that differences among experimental treatments were similar at all weeks regardless the stage of lactation (Fig. 2). Effects on milk components (fat, protein and total solids) output, however, were more noticeable at early than at late stages of lactation, suggesting that milking omission may be more influential when animals are closer to the peak of lactation rather than towards the end of the lactation.

As regards milk composition, the most important changes observed that could be attributed to the omission treatments were found with $T_{2}$ and affected mainly the milk fat content. Fat is the milk component subject to largest fluctuations during lactation (Akers, 2002). The increase observed in fat concentration after omission could be caused by a decrease in total daily milk production (Rémond et al. 2004) or by changes in the regulatory mechanisms of fat secretion related to the aqueous stage of the milk (Davis et al. 1999). The accumulation of milk caused by milking omission would also explain the greater daily protein, fat and total solids yields after the omission of one or two milkings (see Table 3), whereas no significant variations were found in the milk collected before the omission. The fact that differences were larger during the weeks 9 and 13 after lambing than in late lactation (week 16) would confirm that effects of milking omission may vary with stage of lactation.

Finally, some authors have suggested that a reduction in the number of milkings can negatively affect udder health (O'Brien et al. 2002), but this possible adverse effect has not been demonstrated in dairy cattle (Holmes et al. 1992; Ayadi et al. 2003), goats (Salama et al. 2003) or ewes when one or two milkings per week are eliminated (Huidobro, 1988; Casu \& Labussière, 1972; Labussière et al. 1974). In the present study, counts recorded during lactation were relatively constant $\left(112 \times 10^{3}\right.$ cell $\mathrm{s} / \mathrm{ml})$, in contrast with results reported by Holmes el al. (1992) where SCC was higher when some milkings were omitted, probably due to alterations in the physical and/or physiological conditions of the secretory tissue (i.e. leaky tight junctions between mammary epithelial cells; McKusick et al. 2002) as result of the rise in the intramammary pressure. Despite the slight increase observed in treatment $\mathrm{T}_{2}$ after the milking omission, SCC was always far below that considered as indicative of possible pathologies (e.g. subclinical mastitis) (Romeo et al. 1994; Marco et al. 1997), taking into account that these counts are highly variable from animal to animal (Ayadi et al. 2003).

In conclusion, the results of this experiment suggest that the omission of one milking weekly would not 
significantly affect milk production in Spanish Assaf dairy ewes. Therefore, adopting this milking schedule (i.e. omitting one evening milking per week) could be an interesting alternative to allow for a break in the farmers' activity and so an improvement of their quality of life.

The authors gratefully acknowledge Cipriano de Lera (Toral de los Guzmanes, León, Spain) for his collaboration. G Hervás and JL Ramella acknowledge receipt of a research contract (Programa 13P) from the Spanish National Research Council (CSIC, Spain) supported by the European Social Fund and a predoctoral fellowship from the Universidade do Estado de Santa Catarina (UDESC, Brazil), respectively.

\section{References}

Akers RM 2002 Lactation and the Mammary Gland. Ames IO, USA: lowa State University Press

Ayadi M, Caja G, Such X \& Knight CH 2003 Effect of omitting one milking weekly on lactational performances and morphological udder changes in dairy cows. Journal of Dairy Science $\mathbf{8 6}$ 2352-2358

Castillo V, Such X, Caja G, Casals R \& Albanell E 2005 Effect of one $v$. two daily milkings on milk production and composition in Manchega and Laucane ewes. ITEA Producción Animal 26 (Vol. Extra) $252-254$

Casu S \& Labussière J 1972 First results concerning the omitting of one or two milkings per week in Sardinian ewes. Annales de Zootechnie $21233-232$

Davis SR, Farr VC \& Stelwagen K 1999 Regulation of yield loss and milk composition during once-daily milking: a review. Livestock Production Science $\mathbf{5 9}$ 77-94

Davis SR, Farr VC, Copeman PJA, Carruthers VR, Knight CH \& Stelwagen K 1998 Partitioning of milk accumulation between cisternal and alveolar compartments of the bovine udder: relationship to production loss during once daily milking. Journal of Dairy Research $\mathbf{6 5}$ $1-8$

Dulin AM, Paape MJ \& Wergin WP 1982 Differentiation and enumeration of somatic cells in goats milk. Journal of Food Protection $\mathbf{4 5}$ 435-439

FAO 2004 FAOSTAT Statistical Database. URL: http://apps.fao.org (last updated December 2004)

Geenty KG \& Davison PG 1982 Influence of weaning age, milking frequency and udder stimulation on dairy milk production and post partum oestrus interval in Dorset ewes. New Zealand Journal of Experimental Agriculture 10 1-5

Holmes CW, Wilson GF, MacKenzie DDS \& Purchas J 1992 The effects of milking once daily throughout lactation on the performance of dairy cows grazing on pasture. Proceedings of New Zealand Society of Animal Production 52 13-16

Huidobro F 1988 Effect of omission of the Sunday evening milking in Manchega dairy ewes. ITEA Producción Animal 78 33-37

IDF 1984 Recommended methods for somatic cell counting in milk. International Dairy Federation, Doc. No. 168, 4-13. Brussels, Belgium

IDF 1991 Milk somatic cells count. International Dairy Federation Standard, 148, 6-8. Brussels, Belgium

Knight CH \& Dewhurst RJ 1994 Once-daily milking of dairy cows: relationship between yield loss and cisternal milk storage. Journal of Dairy Research 61 441-449
Knight TW \& Gosling LS 1995 Effects of milking frequency and machinestripping on the yield and composition of milk from Poll Dorset ewes. New Zealand Journal of Agricultural Research 38 123-130

Labussière J 1988 Review of the physiological and anatomical factors influencing the milking ability of ewes and the organization of milking. Livestock Production Science 18 253-274

Labussière J, Combaud JF \& Petrequin P 1974 Effects of the suppression of Sunday evening milking of ewes of the Préalpes du Sud breed. Annales de Zootechnie 23 435-444

Mantecón AR \& Lavín P 2001 Assaf dairy sheep: present and future. Mundo Ganadero 136 68-72

Mantecón AR 1999 Global analysis (production-industrializationcommercialization) of dairy goat and sheep production. In Producción de leche y elaboración de quesos de rumiantes menores, pp. 25-42. (Eds R Catalano, C González \& AR Mantecón). Tandil, Argentina: Facultad de Ciencias Veterinarias UNCPBA

Marco JC, Romeo M \& Contreras A 1997 Udder health in dairy sheep. In Ovino de leche: Aspectos claves (Ed. C Buxadé-Carbó). Madrid, Spain: Ediciones Mundi-Prensa

Martínez S, Mantecón AR, Chico MD, Anel L, Álvarez M, Jurado JJ, Diaz C, Pérez J \& Aparicio N 1999 Historical antecedents and bases of a genetic improvement program of Spanish Assaf dairy ewes, 37 pp. Estación Agrícola Experimental, Consejo Superior de Investigaciones Científicas (CSIC), León, Spain

McKusick BC, Thomas, DL, Berger YM \& Marnet PG 2002 Effect of milking interval on alveolar versus cisternal milk accumulation and milk production and composition in dairy ewes. Journal of Dairy Science 85 2197-2206

Mikus M, Knazovicky F, Bendik J \& Gasareck J 1983 Study of the milking aptitudes and milkability in some dairy sheep breeds in the "Mediterranean Basin". In III Symposium Internacional de Ordeño Mecánico en Pequeños Rumiantes, Valladolid, Spain, pp. 730-792

O'Brien B, Ryan G, Meaney WJ, McDonagh D \& Kelly A 2002 Effect of frequency of milking on yield, composition and processing quality of milk. Journal of Dairy Research 69 367-374

Paape MJ, Hafs HD \& Snider WW 1963 Variation of estimated numbers of milk somatic cells stained with Wright's stain or Pyronin Y-methyl green stain. Journal of Dairy Science 46 1211-1216

Papachristoforou C, Roushias A \& Mavrogenis AP 1982 The effect of milking frequency on the milk production of Chios ewes and Damascus goats. Annales de Zootechnie 31 37-46

Peaker M 1980 The effect of raised intramammary pressure on mammary function in the goat in relation to the cessation of lactation. Journal of Physiology (London) 301 415-428

Pollott GE \& Gootwine E 2004 Reproductive performance and milk production of Assaf sheep in an intensive management system. Journal of Dairy Science 87 3690-3703

Rémond B, Pomièsb D, Dupont D \& Chilliard Y 2004 Once-a-day milking of multiparous Holstein cows throughout the entire lactation: milk yield and composition, and nutritional status. Animal Research 53 201-212

Romeo M, Esnal A, Contreras A, Aduniz J, González L \& Marco J 1994 Evolution of milk somatic cell counts along the lactation period in sheep of the Latxa breed. In International Symposium Somatic Cells and Milk of Small Ruminants, Bella, Italy pp. 6-9

Salama AAK, Such X, Caja G, Rovai M, Casals R, Albanell E, Marín MP \& Martí A 2003 Effects of once versus twice daily milking throughout lactation on milk yield and milk composition in dairy goats. Journal of Dairy Science 86 1673-1680

SAS 1999 SAS OnlineDoc ${ }^{\circledR}$, Version 8. Cary NC, USA: SAS Institute Inc.

Ugarte E, Ruiz R, Gabina D \& Beltrán de Heredia I 2001 Impact of highyielding foreign breeds on the Spanish dairy sheep industry. Livestock Production Science 71 3-10 